Aldona Klimkiewicz

Higher School of Economics and Management in Lodz

e-mail: aldona.klimkiewicz@wp.pl

\title{
Obniżenie wieku emerytalnego w Polsce Implikacje dla kobiet w sferze rynku pracy
}

\section{Lowering the Retirement Age in Poland. Implications for Women in the Area of Employment}

The subject of the publication is the analysis of the situation of women in the labour market in terms of lowering the retirement age. The reinstatement of quite a low retirement age threshold which makes women eligible for retirement indicates a change in their position in the area of employment.

Manipulating the retirement age is a basic instrument of influence on pension schemes and the formation of human resources for labour markets in European countries, the latter affected by the ageing of the population. A dominant trend is to raise the age limit in order to increase manpower resources and to cut back public expenditure on benefits.

Without a doubt, the lowering of the retirement age in Poland will have a number of socioeconomic consequences, which will include an outflow of women from the labour market, and a depletion of manpower resources, which in turn may result in lessened migratory pressure. However, the thesis can be advanced that the amount of benefits received, due to a shorter input period, will arouse a greater interest in the option of combining benefit receipt with gainful employment. The solutions adopted in this respect will not only impact the situation of women, but other social groups as well, which will be clearly visible in the response from the labour market.

Keywords: retirement age, woman, pension, labour market.

JEL Classification: J14, J88 


\section{Wprowadzenie}

Przedmiotem publikacji jest analiza sytuacji kobiet na rynku pracy w perspektywie obniżenia wieku emerytalnego. 1 października 2017 r. nastąpi zróżnicowanie w oparciu o kryterium płci i jednocześnie obniżenie ustawowego wieku emerytalnego kobiet do 60. roku życia oraz wieku emerytalnego mężczyzn do 65. roku życia. Powrót do dość niskiej granicy wieku uprawniającego kobiety do przejścia na emeryturę oznacza zmiany w ich sytuacji osobistej i rodzinnej oraz wywoła daleko idące konsekwencje w sferze zatrudnienia. Artykuł koncentruje się głównie na zawodowych konsekwencjach obniżenia wieku emerytalnego kobiet, z pobieżnym potraktowaniem kwestii demograficznych i dochodowych.

Manipulacja wiekiem emerytalnym stanowi podstawowe narzędzie oddziaływania na systemy emerytalne i instrument kształtowania zasobów ludzkich rynku pracy. W krajach europejskich, dotkniętych procesem starzenia się społeczeństw, tendencją wiodącą jest podwyższanie granicy wieku w celu zwiększenia zasobów siły roboczej i zmniejszenia wydatków publicznych na świadczenia emerytalne. Proces podwyższania wieku emerytalnego zwykle jest rozłożony w czasie i skoordynowany z proaktywnymi działaniami w obszarze rynku pracy na rzecz utrzymania aktywności zawodowej osób w wieku przedemerytalnym. W tym kontekście rezygnacja ze stopniowej indeksacji wieku w Polsce oznacza odejście od trendów europejskich w zakresie polityki kształtowania wieku emerytalnego.

Abstrahując od przyczyn czy oceny zasadności takiego rozwiązania, należy stwierdzać, że zahamowanie operacji podwyższenia wieku emerytalnego i jednocześnie powrót do granicy 60 lat $\mathrm{w}$ przypadku kobiet w Polsce wywoła szereg konsekwencji o charakterze społeczno-ekonomicznym. Należą do nich odpływ kobiet z rynku pracy i uszczuplenie zasobów siły roboczej, co może skutkować zmniejszeniem presji migracyjnej. Perspektywa dłuższego życia na emeryturze przy otrzymywaniu świadczenia w niższej kwocie (efekt stosowania formuły zdefiniowanej składki) będzie sprzyjała podejmowaniu decyzji o odroczeniu przejścia na emeryturę lub o powrocie na rynek pracy. Można zatem postawić tezę, że wysokość świadczeń w związku z krótszym okresem oszczędzania na emeryturę spowoduje zwiększone zainteresowanie powrotem do pracy zarobkowej. W związku z tym niezwykle istotne są warunki łączenia pobierania emerytury z dochodami z pracy oraz możliwość przeliczenia wysokości nabytego świadczenia w oparciu o wypracowany staż i kapitał. Okoliczności te będą ważne również dla kształtowania się sytuacji na rynku pracy i decyzji pracodawców w kwestii zatrudniania. Przyjęte w tym obszarze rozwiązania wpłyną nie tylko na sytuację kobiet, lecz również innych grup społecznych, co uwidoczni się w reakcji rynku pracy. 


\section{Zmiany dotyczące granicy wieku emerytalnego $w$ systemie emerytalnym}

Przez kilkanaście ostatnich lat w Polsce podejmowano działania mające na celu złagodzenie niekorzystnego wpływu procesów demograficznych na finanse funduszy emerytalnych, a w konsekwencji budżet państwa. Starania reformatorów skupiały się na zachowaniu stabilności finansowej systemu emerytalnego, a także na zapewnieniu adekwatności emerytur. Do najważniejszych modyfikacji dokonanych w tym czasie można zaliczyć: zmianę formuły wymiaru emerytury, wprowadzenie wielofilarowej konstrukcji systemu emerytalnego, zastosowanie mieszanego finansowania repartycyjno-kapitałowego, znaczne ograniczenie dostępu do wcześniejszych emerytur, wprowadzenie emerytur pomostowych, a także podwyższenie i zrównanie wieku emerytalnego docelowo do 67 lat dla obu płci.

Przeprowadzone w polskim systemie emerytalnym modyfikacje nie odbiegały od działań podejmowanych w pozostałych krajach UE ${ }^{1}$. Wyniki prognoz demograficznych wskazują bowiem, że europejskie społeczeństwa się starzeją. Do 2030 roku połowa populacji Europy Zachodniej będzie miała ponad 50 lat, a oczekiwana długość dalszego życia dla osób w tym wieku wyniesie 40 lat $^{2}$. W Polsce proces ten prowadzi do istotnych zmian w strukturze wiekowej ludności, oddziałujących na rynek pracy. Przede wszystkim obserwowany jest znaczny ubytek rąk do pracy wynikający z niskiej od kilkudziesięciu lat dzietności, niezapewniającej prostej zastępowalności pokoleń, oraz wydłużającego się trwania życia.

Stopniowe podwyższanie wieku emerytalnego w Polsce, prowadzące do jego docelowego ujednolicenia, miało pozytywnie wpłynąć na kształtowanie zasobów pracy oraz finanse systemu emerytalnego. Podwyższeniem wieku emerytalnego objęto kobiety urodzone po 31 grudnia 1952 r. oraz mężczyzn urodzonych po 31 grudnia 1947 r. Proces ten rozpoczął się 1 stycznia 2013 r. i miał zakończyć się dla mężczyzn w 2020 r., a dla kobiet w 2040 r. Rozłożenie operacji w czasie, zwłaszcza w stosunku do kobiet, stwarzało szanse na przystosowanie wszystkich uczestników rynku pracy do nowej granicy wieku emerytalnego. W uzasadnieniu ${ }^{3}$ do projektu ustawy podwyższającej wiek emerytalny ${ }^{4}$ zostały podkreślone wielowymiarowe korzyści zarówno dla finansów publicznych, jak i dla przyszłych świadczeniobiorców. Wskazano na potrzebę podwyższenia wieku emerytalnego ze względu na rosnącą oczekiwaną długość życia, która bezpośrednio wpływa na wysokość otrzymywanych świadczeń. Niemniej jednak zaznaczono, że procesowi

\footnotetext{
${ }^{1}$ Szerzej: G. Uścińska, Problemy wspótczesnych systemów emerytalnych - kierunki rozwiązań w zakresie wieku emerytalnego, ,Praca i Zabezpieczenie Społeczne” 2011, nr 4; B. Kłos, Europejskie systemy emerytalne - stan i perspektywy, Biuro Analiz Sejmowych, „Analizy” 2011, nr 5; M. Dybał, Reformy systemów emerytalnych, ,Zarządzanie i Finanse” 2013, nr 2, s. 289-303; Z. Czepulis-Rutkowska, Trendy w funkcjonowaniu systemów emerytalnych w Europie, ,Polityka Społeczna” 2016, nr 11-12, s. 2-3.

${ }^{2}$ ISSA, Social Policy Highlight 12, http://www.ageing.ox.ac.uk/download/77 (data dostępu: 2.04.2017).

${ }^{3}$ Por. Uzasadnienie do rzadowego projektu ustawy o zmianie ustawy o emeryturach $i$ rentach z FUS (druk 329), http://www.sejm.gov.pl (data dostępu: 14.03.2017).

${ }^{4}$ Ustawa z dnia 11 maja 2012 r. o zmianie ustawy o emeryturach i rentach z Funduszu Ubezpieczeń Społecznych oraz niektórych innych ustaw, Dz.U. z 2012 r. poz. 637 (dalej: ustawa podwyższająca).
} 
podwyższania wieku winny towarzyszyć działania zachęcające do wydłużenia aktywności zawodowej przez osoby w wieku przedemerytalnym. Z drugiej strony podwyższanie wieku emerytalnego nie zostało dokonane $\mathrm{z}$ uwzględnieniem czynników biologicznych, związanych z naturalnym zjawiskiem starzenia się organizmu i stopniową utratą przez ludzi zdolności do wykonywania pracy zarobkowej. Tendencji do rosnącej oczekiwanej długości życia w Polsce towarzyszy proces wydłużania się okresu życia w dobrym zdrowiu, lecz charakteryzuje go zdecydowanie wolniejsze tempo.

Dla złagodzenia dokonywanych zmian wprowadzono nowe świadczenie o charakterze okresowym, tzw. emeryturę częściową dla osób legitymujących się znacznym stażem ubezpieczeniowym. Brak warunku rozwiązania stosunku pracy wskazywał adresatów takiego rozwiązania - zostało ono skierowane do starszych pracowników niezdolnych już do wykonywania obowiązków zawodowych w pełnym wymiarze. Jednakże istotnym mankamentem emerytury częściowej było zmniejszanie podstawy obliczenia świadczenia docelowego, co pod względem dochodowym stawiało kobiety w jeszcze gorszej sytuacji.

\section{Mechanizm obniżenia wieku emerytalnego od 1 października 2017 roku}

Długofalowy pozytywny efekt podejmowanych działań mających racjonalizować finanse publiczne zostanie znacznie osłabiony na skutek wprowadzenia 1 października 2017 r. obniżenia granicy wieku emerytalnego do jej poprzedniej wysokości, tj. 60 lat dla kobiet i 65 lat dla mężczyzn ${ }^{5}$. Do tego czasu osoby uprawnione nabywają prawa emerytalne zgodnie $\mathrm{z}$ harmonogramem przewidzianym $\mathrm{w}$ ustawie podwyższającej wiek emerytalny. W uzasadnieniu do prezydenckiego projektu ustawy obniżającej wiek emerytalny podważono zasadność operacji go podwyższającej, wskazując, że

obecna sytuacja spoleczno-gospodarcza Polski nie uzasadnia podwyższenia podstawowego wieku emerytalnego, a także rynek pracy oraz system publicznej opieki zdrowotnej $w$ Polsce nie byly i nadal nie sa przygotowane na wydlużenie okresu aktywności zawodowej ubezpieczonych. Dlatego też podwyższenie wieku emerytalnego nie przyniesie zakładanych, pozytywnych efektów ${ }^{6}$.

Oszczędności poczynione w systemie emerytalnym zostaną zniwelowane przez wydatki związane $\mathrm{z}$ wypłatą rent $\mathrm{z}$ tytułu niezdolności do pracy, zasiłków dla bezrobotnych czy też świadczeń przedemerytalnych. Podkreślono również, że przywrócenie poprzedniej granicy wieku emerytalnego ma stworzyć ubezpieczo-

\footnotetext{
${ }^{5}$ Ustawa z dnia 16 listopada 2016 r. o zmianie ustawy o emeryturach i rentach z Funduszu Ubezpieczeń Spolecznych oraz niektórych innych ustaw, Dz.U. z 2017 r. poz. 38 (dalej: ustawa zmieniająca).

${ }^{6}$ Por. Uzasadnienie do prezydenckiego projektu ustawy o zmianie ustawy o emeryturach $i$ rentach z FUS (druk 62), http://orka.sejm.gov.pl (data dostępu: 17.03.2017).
} 
nym możliwość wyboru momentu opuszczenia rynku pracy. Decyzja ta jest uzależniona od wielu indywidualnych czynników, takich jak sytuacja ekonomiczna pracodawcy, perspektywy znalezienia innego zatrudnienia, kwalifikacje zawodowe ubezpieczonego, oczekiwania co do poziomu życia po zakończeniu okresu aktywności zawodowej, inne formy aktywności, jego stan zdrowia czy samopoczucie ${ }^{7}$.

Warto zauważyć, że wprowadzając obniżenie wieku emerytalnego nie dokonano jego ujednolicenia, lecz przywrócono zróżnicowany jego próg ze względu na płeć. Tym samym kobiety będą mogły skorzystać z uprawnień emerytalnych 5 lat wcześniej niż mężczyźni. Krótszy czas wnoszenia składek do systemu emerytalnego oraz zwiększona liczba miesięcy pobierania emerytury przełożą się na znacznie niższe świadczenie niż w przypadku nabycia praw emerytalnych w wieku 67 lat.

\section{Wpływ obniżenia wieku emerytalnego kobiet na wysokość emerytur}

Wyliczenie świadczenia nabywanego w niższym wieku emerytalnym od 1 października 2017 r. będzie odbywało się w oparciu o formułę zdefiniowanej składki, w której wysokość świadczenia jest wypadkową wpłaconych składek, poddawanych procesowi waloryzacji lub inwestowania, oraz przeciętnego dalszego trwania życia w momencie przejścia na emeryturę. Takie rozwiązanie pozwala na indywidualizację świadczenia oraz respektowanie zasady ekwiwalentności. Wkład do systemu jest uzależniony nie tylko od wartości poszczególnych składek, ale również ich liczby powiązanej z okresem aktywności zawodowej. Ubezpieczony w celu uzyskania jak najwyższego świadczenia emerytalnego powinien wykazać aktywną postawę prozatrudnieniową, dążąc do zachowania ciągłości pracy oraz opóźniania momentu zakończenia aktywności zawodowej.

Skutki obniżenia wieku emerytalnego odczują przede wszystkim kobiety. Dla nich przeciętne świadczenie w wyniku dokonanych zmian będzie niższe o prawie 1000 zł w 2030 r. i około 3000 zł w 2060 r. W tym czasie mężczyźni otrzymają emerytury niższe odpowiednio o 732 zł i $952 \mathrm{zł}^{8}$. Tak znaczne zmniejszenie wysokości emerytur będzie miało wpływ na pogorszenie sytuacji dochodowej świadczeniobiorców. Niska emerytura obliczona na podstawie własnego wkładu może powodować, że wielu beneficjentów, zwłaszcza kobiet, będzie nabywało prawo do emerytury minimalnej. Świadczenie to ma stanowić odpowiednik dochodów pozwalających na zaspokojenie potrzeb na poziomie co najmniej minimum socjalnego $^{9}$. W przypadku, gdy wysokość emerytury, obliczonej w oparciu o zgromadzony

\footnotetext{
${ }^{7}$ Ibidem.

${ }^{8}$ Załacznik do projektu Stanowiska Rady Ministrów wobec prezydenckiego projektu ustawy o zmianie ustawy o emeryturach i rentach z. Funduszu Ubezpieczeń Społecznych oraz niektórych innych ustaw (druk nr 62); http://orka.sejm.gov.pl (data dostępu: 11.03.2017).

${ }^{9}$ Szerzej: A. Klimkiewicz, Nowa emerytura jako element warunkujacy godny poziom życia, „Annales. Etyka w Życiu Gospodarczym" 2011, vol. 14, nr 2, s. 165 i n.
} 
przez ubezpieczonego zasób, jest mniejsza niż kwota najniższej emerytury, podwyższa się ją, aby nie była ona niższa od świadczenia minimalnego. Ubezpieczony musi jednak spełnić określone warunki, tj. ukończyć wiek emerytalny oraz posiadać określoną długość okresu składkowego i nieskładkowego ${ }^{10}$. Ze względu na przesunięcie granicy wieku emerytalnego liczbę wymaganych okresów stażu ubezpieczeniowego zwiększono do 25 lat. Ustawa zmieniająca złagodziła warunki jej uzyskania, przywracając od 1 października 2017 r. uprzednią wysokość wskazanych okresów, tj. 20 lat dla kobiet i 25 lat dla mężczyzn.

Jak już wspomniano, wyższy wiek emerytalny, połączony z przedłużoną aktywnością zawodową, sprzyjał wzrostowi wartości emerytur, czego konsekwencją byłaby konieczność dopłat do świadczenia minimalnego jedynie w stosunku do około $20 \%$ kobiet. Natomiast powrót do niższej granicy wieku emerytalnego może dać efekt w postaci dwukrotnego zwiększenia liczby uprawnionych osób. Szacuje się, że od 2040 r. połowa emerytów będzie otrzymywała świadczenie minimalne, a ich procent będzie stale wzrastał. Ponadto około $70 \%$ osób urodzonych na przełomie lat 80. i 90. będzie mogło liczyć tylko na najniższą emeryturę. Ze względu na fakt, że dopłaty będą finansowane z budżetu państwa, ciężar ich pokrycia zostanie przerzucony na przyszłe pokolenia pracujących ${ }^{11}$.

\section{Wyzwania dla rynku pracy w kontekście zmian demograficznych}

\subsection{Kształtowanie zasobów rynku pracy do 2050 roku}

Celem polityki rynku pracy jest utrzymanie stabilnej liczby osób aktywnych zawodowo, zapewnienie pełnego i produktywnego zatrudnienia odpowiednio dla potrzeb gospodarki i finansów publicznych. Realizacja tych zamierzeń stanowi warunek niezbędny dla prawidłowego funkcjonowania systemu emerytalnego. Bez względu na przyjętą metodę finansowania - repartycyjną, kapitałową lub kombinację obu - w ramach systemów emerytalnych dokonywany jest podział łącznej produkcji pomiędzy osobami aktywnymi zawodowo i emerytami. Istnieje wobec tego potrzeba utrzymania w zatrudnieniu oraz zaktywizowania jak największej liczby osób ${ }^{12}$. Jednakże w obliczu obserwowanych i przewidywanych zmian w strukturze wiekowej polskiego społeczeństwa oraz biorąc pod uwage poziom zatrudnienia okazuje się, że będzie to cel dość trudny do realizacji.

\footnotetext{
${ }^{10}$ Art. 87. ustawy z dnia 17 grudnia 1998 r. o emeryturach i rentach z Funduszu Ubezpieczeń Społecznych, Dz.U.2016.887 ze zm. (dalej: ustawa emerytalna).

${ }^{11}$ M. Malec, J. Tyrowicz, Niski wiek emerytalny, wysoka cena [w:] Starzenie się ludności, rynek pracy i finanse publiczne $w$ Polsce, red. P. Lewandowski, J. Rutkowski, Instytut Badań Strukturalnych, Unia Europejska 2017, s. 30.

${ }^{12}$ M. Żukowski, Systemy emerytalne a aktywność zawodowa - $w$ Polsce i innych krajach UE [w:] Aktywizujaca polityka społeczna, red. J. Orczyk, M. Żukowski, „Zeszyty Naukowe” nr 89, Wydawnictwo Akademii Ekonomicznej w Poznaniu, Poznań 2007, s. 116 i n.
} 
W Polsce, będącej jednym z młodszych unijnych państw, grupa osób w wieku $65+$ stanowić będzie prawie $1 / 3$ populacji. Zwiększy się mediana wieku ludności z 39,6 lat w 2015 r. do 50,7 w 2050 r. ${ }^{13}$ Prognoza wskazuje, że w Polsce do 2050 r. nastąpi spadek liczby osób w wieku 15-64 lat o 8,3 $\mathrm{mln}^{14}$. Ludność w wieku produkcyjnym mobilnym (18-44 lat) zostanie uszczuplona o 6 mln osób, a nasilenie tego zjawiska będzie miało miejsce w latach 2020-2035. Przez wszystkie objęte prognozą lata liczba osób w wieku niemobilnym (45-59/64) spadnie o około 1,8 mln. Mamy zatem do czynienia z zaawansowanym starzeniem demograficznym zasobów pracy, co oznacza, że mniej będzie osób w wieku produkcyjnym, i będą one starsze niż dotychczas. Utrzymanie wyższego wieku emerytalnego pozwoliłoby na zachowanie liczby starszych pracowników na poziomie z $2013 \mathrm{r}^{15}$

Zmniejszenie zasobów pracy oznacza spadek tempa rozwoju gospodarczego, chyba że wzrośnie produktywność i ulegnie zwiększeniu zatrudnienie, m.in. poprzez dłuższą aktywność zawodową osób w wieku przedemerytalnym. Warunkiem realizacji tej idei jest prowadzenie polityki rynku pracy sprzyjającej aktywności zawodowej wskazanych osób, w tym zmiany nastawienia zarówno pracodawców, jak i pracobiorców.

\subsection{Poziom zatrudnienia w Polsce i krajach Unii Europejskiej}

W strategii „Europa 2020” wyznaczono cel, jakim jest osiągnięcie zatrudnienia na poziomie $75 \%$ dla państw Unii Europejskiej do 2020 r. ${ }^{16}$ Do tego czasu dla Polski wskaźnik zatrudnienia osób w wieku 20-64 lata ma kształtować się na poziomie $71 \%{ }^{17}$. W związku z tym ważne staje się pozyskanie wszystkich potencjalnych zasobów, którymi może dysponować rynek pracy. Chodzi tutaj zwłaszcza o zaktywizowanie osób ze starszych grup wiekowych. Generacja 50+ stanowi grupę o dużym potencjale zawodowym, mogącą uzupełnić braki siły roboczej wynikające z migracji zawodowej młodych Polaków oraz niskiego przyrostu naturalnego.

O tym, że zasoby te nie są w pełni wykorzystywane, świadczą wartości wskaźnika zatrudnienia w 2010 r. i 2016 r. (tabela 1). Dla Polski były one w każdym analizowanym przypadku niższe niż średnie unijne dla 28 państw, chociaż różnica pomiędzy ich wartościami w 2016 r. była mniejsza od obserwowanej w 2010 r. W 2016 r. wartości tych wskaźników znacząco wzrosły zarówno dla UE28, jak i dla Polski. Uwagę zwracają wartości wskaźnika zatrudnienia starszych osób w obu analizowanych latach. W 2010 r. jego wartość była niższa o 12,1 pkt proc. od odnotowanej dla UE28, a w 2016 r. różnica ta zmniejszyła się do 9,1 pkt proc. Badanie z podziałem na płeć wskazywało na dużo większą rozbieżność wartości dla kobiet (w 2010 r. było to 14,3 pkt proc., a w 2016 r. 11,03 pkt proc.) niż dla mężczyzn (odpowiednio 9,3 pkt proc. i 6,3 pkt proc.) w porów-

\footnotetext{
${ }^{13} \mathrm{http}: / /$ appsso.eurostat.ec.europa.eu/nui/show.do?dataset=proj_15ndbims\&lang=en (data dostępu: 13.04.2017).

${ }^{14}$ GUS, Prognoza ludności na lata 2014-2050, „Studia i Analizy Statystyczne”, Warszawa 2014, s. 131.

${ }^{15}$ GUS, op. cit., s. $148-149$.

${ }^{16}$ http://eur-lex.europa.eu/LexUriServ/LexUriServ.do?uri=COM:2010:2020:FIN:PL:PDF (data dostępu: 5.04.2017).

${ }^{17} \mathrm{http}: / /$ ec.europa.eu/europe2020/pdf/annexii_en.pdf (data dostępu: 5.04.2017).
} 
naniu do średniej unijnej. Różnice były jeszcze większe w zestawieniu z krajami osiągającymi ponadprzeciętne wartości tych wskaźników, i tak w 2016 r. w Szwecji zatrudnionych było 75,5\% osób w wieku 55-64 lata, w Niemczech 68,6\%, w Danii $67,8 \%$, w Estonii $65,2 \%$ oraz na Litwie $64.6 \%$. Wysokie zatrudnienie starszych osób okazało się możliwe do osiągnięcia nie tylko przez państwa Europy Zachodniej, lecz również kraje postkomunistyczne. Rodzi to szansę efektywnej aktywizacji tej grupy, a zwłaszcza starszych kobiet, i tym samym wzrostu zatrudnienia w Polsce.

Tabela 1. Wskaźnik zatrudnienia w grupie wiekowej 20-64 w UE28 i w Polsce w 2010 r. i 2016 r. $(\%)$

\begin{tabular}{|l|c|c|c|c|}
\hline \multirow{2}{*}{\multicolumn{1}{|c|}{ Wyszczególnienie }} & \multicolumn{2}{c|}{2010} & \multicolumn{2}{c|}{$\mathbf{2 0 1 6}$} \\
\cline { 2 - 5 } & UE28 & Polska & UE 28 & Polska \\
\hline zatrudnienie ogólem osób w wieku 20-64 lata & 68,6 & 64,3 & 71,1 & 69,3 \\
\hline mężczyźni & 75,1 & 71,3 & 76,9 & 76,4 \\
\hline kobiety & 62,1 & 57,3 & 65,3 & 62,2 \\
\hline zatrudnienie ogółem osób w wieku 55-64 lata & 46,2 & 34,1 & 55,3 & 46,2 \\
\hline mężczyźni & 54,5 & 45,2 & 62,0 & 55,7 \\
\hline kobiety & 38,5 & 24,2 & 48,9 & 37,6 \\
\hline
\end{tabular}

Źródło: opracowanie własne na podstawie: http://ec.europa.eu/eurostat/web/lfs/data/maintables (data dostępu: 20.04.2017).

\subsection{Instrumenty prawne ochrony pracowników w okresie przedemerytalnym}

Analizując sytuację kobiet na rynku pracy w związku z obniżeniem wieku emerytalnego, nie sposób pominąć pewnych instrumentów prawnych bezpośrednio wpływających na ich szanse na zatrudnienie.

Należy do nich zaliczyć w pierwszej kolejności przepisy zakazujące dyskryminacji na rynku pracy, w szczególności ze względu na płeć i wiek, co oznacza, że te kryteria nie mogą stanowić bariery zatrudnienia, jak również pracodawca nie może ich wykorzystać jako bezpośredniej przyczyny rozwiązania stosunku pracy. Nakaz stosowania zasady równości przy korzystaniu z pośrednictwa pracy, wyrażony w art. 36 ust. 4 pkt 3 ustawy o promocji zatrudnienia ${ }^{18}$, również dotyczy płci i wieku. Te same kryteria nie mogą negatywnie wpłynąć na sytuację kobiety w sferze nawiązania, realizacji i rozwiązania stosunku pracy $\mathrm{w}$ rozumieniu art. $18^{3 \mathrm{a}} \mathrm{k} . \mathrm{p} .{ }^{19}$ i następnych.

Niezmiernie ważną regulacją jest art. 39 k.p., zgodnie z którym pracodawca nie może wypowiedzieć umowy o pracę pracownikowi, któremu brakują nie więcej niż 4 lata do osiągnięcia wieku emerytalnego, jeżeli okres zatrudnienia umożliwia mu uzyskanie prawa do emerytury z osiągnięciem tego wieku. Celem wskazanej regulacji jest ochrona osób znajdujących się w okresie przedemerytalnym. Wiek okołoemerytalny należy do cech społeczno-demograficznych, których wy-

${ }^{18}$ Ustawa z dnia 20 kwietnia 2004 r. o promocji zatrudnienia i instytucjach rynku pracy, tekst jedn., Dz.U. z 2016 r., nr 645 ze zm., (dalej jako: ustawa o promocji zatrudnienia).

${ }^{19}$ Ustawa z dnia 26 czerwca 1974 r. - Kodeks pracy, Dz.U. z 2016 r. poz. 1666, 2138 i 2255. 
stąpienie powoduje wyższe zagrożenie ryzykiem bezrobocia ${ }^{20}$, a w konsekwencji zmniejszenie szans na nabycie uprawnień emerytalnych bądź na wypracowanie świadczenia o odpowiedniej wysokości. Warto przypomnieć, że bezrobotni powyżej 50. roku życia są zaliczani do osób w szczególnej sytuacji na rynku pracy na gruncie art. 49 ustawy o promocji zatrudnienia, w związku z tym mogą liczyć na wiele specjalnych instrumentów przeciwdziałania bezrobociu, skierowanych bezpośrednio do nich. Art. 39 k.p. stanowi zatem jeden z przejawów wykorzystania prawa w celu polepszenia sytuacji na rynku pracy osób w starszym wieku, z tym że jego działanie jest ukierunkowane na utrzymanie posiadanego zatrudnienia.

Wprowadzanie instrumentów ochronnych jest uzasadniane faktycznym mniejszym zainteresowaniem pracodawców pracownikami generacji $50+$ ze względu na ich niższe predyspozycje, wynikające chociażby $\mathrm{z}$ dezaktualizacji kwalifikacji zawodowych, mniejszą mobilność czy utratę zdolności psychofizycznych do wykonywania pracy. Ta ochrona osób w wieku przedemerytalnym przed wypowiedzeniem stosunku pracy wzmacnia ich pozycję prawną, lecz zdecydowanie osłabia możliwości zatrudnienia. Ze względu na omawiany w tym miejscu zakaz wypowiadania umowy ich szanse na podjęcie pracy są minimalne ${ }^{21}$.

Przywracając niższy wiek emerytalny, ustawodawca w art. 28 ustawy zmieniającej utrzymał czteroletni okres ochronny dla pracowników, którzy w dniu wejścia w życie tej ustawy będą objęci ochroną stosunku pracy wynikającą z art. 39 k.p., lub dla osób, które byłyby objęte taką ochroną, jeżeli w tym dniu pozostawałyby w stosunku pracy. Od dnia wejścia w życie ustawy zmieniającej wskazane osoby będą korzystały z ochrony stosunku pracy do osiągnięcia wieku emerytalnego wynikającego z przepisów ustawy podwyższającej.

Dla osób przechodzących na emeryturę w wieku emerytalnym obowiązującym od 1 października 2017 r. szczególna ochrona wypowiedzenia stosunku pracy obejmie kobiety w wieku 56+ i mężczyzn w wieku 61+.

W związku ze zróżnicowaniem wieku ze względu na płeć kobiety dość szybko wchodzą w okres ochrony przedemerytalnej, co może oznaczać redukcję szans, i tak już dużo mniejszych z racji samego wieku, na zatrudnienie po ukończeniu pięćdziesiątego roku życia. Pracodawcy są bowiem bardziej skłonni zatrudnić młodą osobę, nawet z niższymi kwalifikacjami, niż osobę w wieku 50+. Oznacza to, że główny cel art. 39 k.p. - stabilizacja stosunku pracy osób w wieku przedemerytalnym i urealnienie uzyskania emerytury - nie będzie realizowany w stosunku do kobiet, będą one bowiem w ocenie pracodawców mniej konkurencyjne. $\mathrm{Z}$ kolei brak statusu pracowniczego sprawia, że mogą liczyć ewentualnie na uzyskanie prawa do świadczenia przedemerytalnego ${ }^{22}$.

Warto również zwrócić uwagę, iż z ochrony przewidzianej art. 39 k.p. nie korzysta taki pracownik, któremu wprawdzie do osiągnięcia wieku emerytalnego brakują nie więcej niż 4 lata, lecz któremu dalsze zatrudnienie nie umożliwia

\footnotetext{
${ }^{20}$ Por. MRPiPS, Osoby powyżej 50. roku życia na rynku pracy w 2015 roku, Departament Rynku Pracy Wydział Analiz i Statystyki, Warszawa 2016.

${ }^{21}$ Kodeks pracy. Komentarz, wyd. III, red. K.W. Baran, Wydawnictwo Wolters Kluwer 2015; LEX/el. 2017 (data dostępu: 18.04.2017).

${ }^{22}$ Ibidem.
} 
uzyskania prawa do emerytury z osiągnięciem tego wieku²3. Sąd Najwyższy wyjaśnił również, że zakaz wypowiedzenia umowy o pracę wynikający z art. 39 nie dotyczy pracownika zatrudnionego $\mathrm{w}$ niepełnym wymiarze czasu pracy i pobierającego jednocześnie emeryturę ${ }^{24}$.

\section{Możliwość lączenia pobierania emerytury z pracą zarobkową stanowiącą tytuł ubezpieczenia społecznego}

Ubezpieczony w momencie osiągnięcia wieku emerytalnego ma prawo wystąpić z wnioskiem o ustalenie prawa do emerytury. Zgodnie z art. 103a ustawy emerytalnej ustawodawca uzależnia realizację uprawnień emerytalnych od uprzedniego rozwiązania stosunku pracy z pracodawcą, przez którego zatrudniony był bezpośrednio przed dniem nabycia prawa do emerytury. W innym przypadku zawieszone zostanie prawo do emerytury bez względu na wysokość przychodu uzyskiwanego przez emeryta. Przyjęte rozwiązanie jest zgodne $\mathrm{z}$ traktowaniem emerytury jako świadczenia zastępczego w stosunku do wynagrodzenia za pracę, a nie jego uzupełnienia.

Emeryt może łączyć pobieranie świadczenia $\mathrm{z}$ pracą zarobkową. Jednak zgodnie $\mathrm{z}$ art. 103 ustawy emerytalnej, prawo do emerytur i rent ulega zawieszeniu lub świadczenia te ulegają zmniejszeniu po przekroczeniu określonych ustawowo limitów, przy czym nie stosuje się tego rozwiązania w stosunku do emerytów, którzy ukończyli 60 lat (kobiety) lub 65 lat (mężczyźni). W konsekwencji osoby, które nabyły prawo do emerytury w powszechnym wieku emerytalnym, mogą łączyć osiąganie dochodów z pracy zarobkowej i pobieranie świadczeń. Znaczenia nie ma w tym przypadku ani wysokość ich zarobków, ani rodzaj działalności, z której zostały uzyskane. Zakładając, że rozwiązanie to nie ulegnie zmianie przy obniżeniu wieku emerytalnego, wysoce prawdopodobne wydaje się, że z możliwości łączenia emerytury z pracą skorzysta znaczna liczba świadczeniobiorców. Wskazuje na to kilka przyczyn. Po pierwsze, będzie to grupa młodsza niż przechodząca na emeryturę zgodnie $\mathrm{z}$ harmonogramem przewidzianym dla podwyższonego wieku emerytalnego, która już poczyniła określone plany zawodowe. Poza tym ważny jest czynnik psychologiczny - w pewnym stopniu osoby te zaakceptowały już dłuższe pozostanie na rynku pracy. Po drugie, możliwość uzupełniania emerytury dochodami z pracy może wydać się kuszącą perspektywą, zwłaszcza przy prognozach dotyczących wysokości świadczenia i przewidywanej długości życia.

\footnotetext{
${ }^{23}$ Cf. wyrok SN z 22 marca 1977 r., I PRN 24/77, LexPolonica nr 317957.

${ }^{24}$ Uchwała SN z 11 czerwca 1991 r., I PZP 19/91, LexisNexis nr 312243, OSNCP 1992, nr 1, poz. 14.
} 
Wskazuje się, że wprowadzenie ograniczenia łączenia pobierania emerytury z pracą przyniosłoby wymierne korzyści dla budżetu państwa i wpłynęło na zmniejszenie liczby osób przechodzących na emeryturę ${ }^{25}$. W przygotowanej przez ZUS publikacji „Biała Księga”26 przedstawiono możliwe do przyjęcia przez prawodawcę warianty łączenia pracy zarobkowej i pobierania emerytury:

(1) pozostawienie dotychczasowych zasad zawieszalności świadczeń,

(2) wprowadzenie całkowitej zawieszalności świadczeń w razie osiągania dodatkowego przychodu $\mathrm{z}$ aktywności ekonomicznej - obowiązującej tylko osoby, które nie osiągnęły powszechnego wieku emerytalnego,

(3) całkowite uwolnienie możliwości łączenia pobierania świadczenia oraz uzyskiwania przychodu z pracy zarobkowej.

Przedstawione przez ZUS warianty mają być efektywne zarówno finansowo, jak i społecznie.

W „Białej Księdze” zaproponowano także rozwiązanie wprowadzające możliwość przechodzenia na emeryturę tylko raz w życiu. Po spełnieniu warunków uprawniających do emerytury należałoby podjąć decyzję o pobieraniu jej lub kontynuacji aktywności zawodowej. Powrót do zatrudnienia wiązałby się obligatoryjnie $\mathrm{z}$ przerwaniem pobierania świadczenia, a emerytura nie byłaby ponownie przeliczana. Ta propozycja jest zbieżna z postulatami zgłaszanymi $\mathrm{w}$ trakcie prac legislacyjnych nad ustawą zmieniającą ${ }^{27}$. Sugerowane rozwiązania, zaostrzające warunki łączenia pracy zawodowej $\mathrm{z}$ emeryturą, mają na celu jak najdłuższe utrzymanie $\mathrm{W}$ zatrudnieniu najstarszych pracowników. W razie wdrożenia tego postulatu będą oni musieli podjąć decyzję o momencie opuszczenia rynku pracy lub o ewentualnym zawieszeniu emerytury w celu kontynuacji zatrudnienia. Dla świadczeniobiorców szczególnie dotkliwy byłby brak możliwości podwyższenia emerytury o kolejne okresy pracy.

Warto się zastanowić, czy możliwe jest zatrzymanie na rynku pracy osób zbliżających się do starości. Wraz ze starzeniem się organizmu następuje stopniowa utrata przez ludzi zdolności do wykonywania pracy zarobkowej. Wobec tego ważna jest nie tylko długość życia, lecz także jego jakość. W 2014 r. oczekiwana długość dalszego życia bez niepełnosprawności dla kobiet w wieku 65 lat była szacowana na 8,1 roku, natomiast dla mężczyzn 7,5 roku $^{28}$. W porównaniu z 2007 rokiem wartości te były o rok wyższe w obu przypadkach ${ }^{29}$, co może świadczyć o powolnym wydłużaniu się oczekiwanej długości życia w zdrowiu. W takim razie zaangażowanie kobiet $\mathrm{w}$ pracę $\mathrm{w}$ okresie okołoemerytalnym jest prawdopodobne. Kobiety nie tracą zdolności do pracy z powodu wieku wcześniej niż mężczyźni, a ustalenie dla nich granicy przechodzenia na emeryturę odmiennej niż dla

\footnotetext{
${ }^{25}$ Szacuje się, że od 1 października 2017 r. z prawa do emerytury może skorzystać 200-300 tys. osób, a w całym $2017 \mathrm{r}$. ich liczba może przekroczyć $0,5 \mathrm{mln}$. Za: http://www.gazetaprawna.pl/artykuly/1025 771,prof-uscinska-550-tys-wnioskow-do-zus-o-emeryture-w-calym-2017-r.html (data dostępu: 15.03.2017).

${ }^{26}$ ZUS, Biała Księga. Przegląd emerytalny. Bezpieczeństwo dzięki odpowiedzialności, 2016, s. 9-10.

${ }^{27}$ Ibidem, s. $10-11$.

${ }^{28} \mathrm{http}: / /$ ec.europa.eu/eurostat/tgm/refreshTableAction.do?tab=table\&plugin=1\&pcode=tsdph220\&lang uage $=$ en (data dostępu 25.04.2017).

${ }^{29} \mathrm{~W} 2011 \mathrm{r}$. wartości te były wyższe od tych przewidywanych w $2014 \mathrm{r}$. i wynosiły odpowiednio 8,3 lat dla kobiet i 7,6 dla mężczyzn.
} 
mężczyzn wynika w głównej mierze z tradycji systemów emerytalnych oraz pełnionych przez nie funkcji opiekuńczych. Dowodzi tego chociażby wiek, jakim wykazują się kobiety i mężczyźni przechodzący na emeryturę. W 2014 r. mężczyznom pierwszorazowo przyznano świadczenie, gdy mieli 61 lat, a kobietom, kiedy osiągały średnio 59,8 lat $^{30}$. Zatem kobiety uzyskiwały świadczenie w wieku porównywalnym z mężczyznami, mimo że granica wieku emerytalnego mężczyzn była już wyznaczona powyżej 65. roku życia.

\section{Podsumowanie}

Należy stwierdzić, że przywrócenie wieku emerytalnego zróżnicowanego na płeć będzie miało charakter jednorazowej operacji, mającej na celu realizację obietnic wyborczych. Pomijając jednak aspekty polityczne, zmiana ta wpłynie na kształtowanie się zasobów siły roboczej i sytuację rynku pracy, choć skonkretyzowanie jej skutków jest dość trudne. Zakres i kierunek oddziaływania będzie zależał zarówno od czynników makroekonomicznych, dotyczących całej gospodarki (poziom bezrobocia, wydatki publiczne, stopień inflacji), jak i od czynników w skali mikro - od sytuacji dochodowej gospodarstw emeryckich po indywidualne preferencje pracowników i pracodawców. Z całą pewnością jednak nastąpi odpływ kobiet z rynku pracy, a wobec zmniejszającego się obecnie bezrobocia może pojawić się deficyt pracowników. Pozytywnymi efektami takiej sytuacji mogą być wzrost konkurencyjności i podwyżka wynagrodzeń, a w odniesieniu do starszych pracowników - wzrost ich atrakcyjności na rynku pracy.

Kobiety w wieku okołoemerytalnym reprezentują znaczny potencjał pracowniczy, choć obecnie wskaźnik zatrudnienia wśród najstarszych grup wiekowych jest dużo niższy niż dla całej populacji w wieku produkcyjnym. Może to być efekt tego, że pracodawcy preferują pracowników młodszych, ale może to być również uwarunkowane oceną kwalifikacji zawodowych i umiejętności starszych pracowników. W przypadku kobiet przerwy w pracy i łączenie obowiązków domowych z zawodowymi nie sprzyjają pogłębianiu kwalifikacji, przez co spada ich atrakcyjność na rynku pracy. Nie bez znaczenia pozostaje nadal stan zdrowia, ponieważ sam fakt dożycia określonego wieku nie przesądza przyjęcia tezy, że osoby te są zdolne do pracy. Zdrowotne uwarunkowania zdolności do pracy z natury rzeczy mają wymiar indywidualny i są bardzo trudne do uwzględnienia w ustawowej granicy wieku emerytalnego. Stąd należałoby wrócić do dyskusji nad elastycznym wiekiem emerytalnym, który pozwoli na indywidualną ocenę możliwości dalszego zatrudnienia i podjęcie racjonalnej decyzji emerytalnej. Do takiego rozwiązania $\mathrm{w}$ istocie zmierzają propozycje przechodzenia na emeryturę tylko raz, $\mathrm{z}$ brakiem możliwości przeliczenia świadczenia po powrocie do pracy.

\footnotetext{
${ }^{30}$ www.zus.pl (data dostępu: 12.04.2017).
} 
Niższy wiek emerytalny skróci aktywność zawodową kobiet i może wpłynąć na ograniczenie możliwości rozwoju zawodowego oraz niższe płace, zwłaszcza w odniesieniu do generacji 50+. Pracodawcy bowiem, uznając, iż inwestycja w podnoszenie bądź uaktualnianie ich kwalifikacji oraz awans zawodowy może się w pełni nie zwrócić, ukierunkują swoje zainteresowanie na młodsze pracownice lub mężczyzn. Kobiety będą również wcześniej niż mężczyźni wchodziły w okres ochrony przed wypowiedzeniem umowy o pracę. Wydaje się, że będzie to ważna okoliczność wpływająca na decyzję dotyczącą zatrudnienia bądź utrzymania w zatrudnieniu pracownicy.

Otwarta pozostaje kwestia uregulowania zasad łączenia wykonywania pracy zarobkowej z pobieraniem emerytury. Obecnie pozostawiono możliwość łączenia emerytury z pracą, co z jednej strony pozwala na uzupełnienie dochodów w okresie poprodukcyjnym, a $\mathrm{z}$ drugiej wpływa na dłuższe pozostawanie w zasobach pracy. Ma to istotne znaczenie zwłaszcza dla kobiet, których świadczenia w wielu przypadkach nie będą wyższe niż minimalna emerytura. Konsekwencją będzie pauperyzacja kobiet na emeryturze, co każe przypuszczać, iż będą egzystowały poniżej poziomu zaspokojenia podstawowych potrzeb i staną się beneficjentkami pomocy społecznej albo, jeśli zdrowie pozwoli - wrócą na rynek pracy bądź będą korzystały ze wsparcia rodzin. Osiągnięcie granicy wieku emerytalnego nie obliguje do starań o ustalenie emerytury, jednak z możliwości tej na pewno skorzysta zdecydowana większość uprawnionych. Niewykluczona jest także presja pracodawców na podjęcie takiej decyzji.

\section{Bibliografia}

Dybał M., Reformy systemów emerytalnych, „Zarządzanie i Finanse” 2013, nr 2.

Czepulis-Rutkowska Z., Trendy $w$ funkcjonowaniu systemów emerytalnych $w$ Europie, „Polityka Społeczna” 2016, nr 11-12.

GUS, Prognoza ludności na lata 2014-2050, „Studia i Analizy Statystyczne”, Warszawa 2014.

ISSA, Social Policy Highlight 12, http://www.ageing.ox.ac.uk/download/77.

Klimkiewicz A., Nowa emerytura jako element warunkujacy godny poziom życia [w:] „Annales. Etyka w Życiu Gospodarczym” 2011, vol. 14, nr 2.

Kłos B., Europejskie systemy emerytalne - stan i perspektywy, Biuro Analiz Sejmowych, „Analizy” 2011, nr 5.

Kodeks pracy. Komentarz, wyd. III, red. K.W. Baran, Wydawnictwo Wolters Kluwer 2015; LEX/el. 2017.

Malec M., J. Tyrowicz, Niski wiek emerytalny, wysoka cena [w:] Starzenie się ludności, rynek pracy $i$ finanse publiczne $w$ Polsce, red. P. Lewandowski, J. Rutkowski, Instytut Badań Strukturalnych, Unia Europejska 2017.

MRPiPS, Osoby powyżej 50. roku życia na rynku pracy w 2015 roku, Departament Rynku Pracy Wydział Analiz i Statystyki, Warszawa 2016. 
Uścińska G., Problemy współczesnych systemów emerytalnych - kierunki rozwiazań w zakresie wieku emerytalnego, „Praca i Zabezpieczenie Społeczne” 2011, nr 4.

ZUS, Biała Księga. Przegląd emerytalny. Bezpieczeństwo dzięki odpowiedzialności. 2016.

Żukowski M., Systemy emerytalne a aktywność zawodowa - w Polsce i innych krajach UE [w:] Aktywizujaca polityka społeczna, red. J. Orczyk, M. Żukowski, „Zeszyty Naukowe" nr 89, Wydawnictwo Akademii Ekonomicznej w Poznaniu, Poznań 2007.

\section{Akty prawne}

Ustawa z dnia 16 listopada 2016 r. o zmianie ustawy o emeryturach i rentach z Funduszu Ubezpieczeń Społecznych oraz niektórych innych ustaw, Dz.U. z 2017 r. poz. 38.

Ustawa z dnia 11 maja 2012 r. o zmianie ustawy o emeryturach i rentach z Funduszu Ubezpieczeń Społecznych oraz niektórych innych ustaw, Dz.U. z 2012 r. poz. 637.

Ustawa z dnia 20 kwietnia 2004 r. o promocji zatrudnienia i instytucjach rynku pracy, tekst jedn. Dz.U. z 2016 r., nr 645 ze zm.

Ustawa z dnia 17 grudnia 1998 r. o emeryturach i rentach z Funduszu Ubezpieczeń Społecznych, Dz.U.2016.887 ze zm.

Ustawa z dnia 26 czerwca 1974 r. - Kodeks pracy, Dz.U. z 2016 r. poz. 1666, 2138 i 2255.

\section{Inne źródla}

Uchwała SN z 11 czerwca 1991 r., I PZP 19/91, LexisNexis nr 312243, OSNCP 1992, nr 1, poz. 14.

Uzasadnienie do prezydenckiego projektu ustawy o zmianie ustawy o emeryturach i rentach z FUS (druk 62), http://orka.sejm.gov.pl.

Uzasadnienie do rządowego projektu ustawy o zmianie ustawy o emeryturach i rentach z FUS (druk 329), http://www.sejm.gov.pl.

Wyrok SN z 22 marca 1977 r., I PRN 24/77, LexPolonica nr 317957.

Załącznik do projektu Stanowiska Rady Ministrów wobec prezydenckiego projektu ustawy o zmianie ustawy o emeryturach i rentach z Funduszu Ubezpieczeń Społecznych oraz niektórych innych ustaw (druk nr 62), http://orka.sejm.gov.pl.

http://appsso.eurostat.ec.europa.eu/nui/show.do?dataset=proj_15ndbims\&lang=en.

http://ec.europa.eu/europe2020/pdf/annexii_en.pdf.

http://ec.europa.eu/eurostat/tgm/refreshTableAction.do?tab=table\&plugin=1\&pcode=tsdph 220\&language $=\mathrm{en}$.

http://eur-lex.europa.eu/LexUriServ/LexUriServ.do?uri=COM:2010:2020:FIN:PL:PDF.

http://www.gazetaprawna.pl/artykuly/1025771, prof-uscinska-550-tys-wnioskow-do-zus-oemeryture-w-calym-2017-r.html.

www.zus.pl. 